DOI: 10.32844/2222-5374-2020-104-2.44

УДК: 343.1

Мірковець Д. М.,

кандидат юридичних наук, доцент,

докторант Національної академії внутрішніх справ

\title{
ПОПЕРЕДНІЙ СУДОВИЙ КОНТРОЛЬ ЯК ГАРАНТІЯ ЗАКОННОСТІ ДОСУДОВОГО РОЗСЛІДУВАННЯ ТА ЗАСІБ ЗАБЕЗПЕЧЕННЯ ПРАВ ОСІБ
}

Актуальність статті полягає в тому, що попередній судовий контроль здійснює превентивний, попереджувальний, запобіжний вплив незацікавленого в результатах досудового розслідування, а отже, неупередженого уповноваженого спеціального суб'єкта - слідчого судді на процесуальні відносини, дії, рішення, пов'язані із можливим обмеженням прав осіб на досудовому розслідуванні. До них, насамперед, належать застосування заходів забезпечення кримінального провадження, проведення слідчих (розшукових) дій. Вирішення слідчим суддею клопотань про надання дозволу на проведення позапланових перевірок у кримінальному провадженні не охоплюється його повноваженнями, визначеними КПК Украӥни, які мають реалізовуватися у передбачений процесуальним законом спосіб, адже не відносяться ні до заходів забезпечення кримінального провадження, ні до слідчих дій, ні до негласних слідчих дій. Це суперечить самій суті судового контролю над діями і рішеннями державних органів з метою захисту прав, свобод та інтересів осіб. Це також суперечить завданню суду як інституції в демократичному суспільстві. З'ясовано, що в ухвалі Київського апеляційного суду зазначено, що розглядаючи клопотання про застосування запобіжного заходу у вигляді тримання під вартою для прийняття законного і обгрунтованого рішення, суд, відповідно національного та міжнародного законодавства повинен врахувати тяжкість кримінального правопорушення, у вчиненні якого підозрюється особа та особисті обставини життя особи, які можуть свідчити на користь збільшення (зменшення) ризику переховування від правосуддя чи інших способів неналежної процесуальної поведінки. Зроблено висновок, що попередній судовий контроль являє сукупність пов'язаних дій щодо перевірки законності рішень і дій органу досудового розслідування (відповідність дій і рішень вимогам законодавства, що регулює діяльність органу досудового розслідування та у межах визначених повноважень), обгрунтованості таких дій і рішень, а також підтвердження або спростування юридичного значення дій і рішень уповноважених органів, що у комплексі забезпечує, крім законності, стабільність, передбачуваність досудового розслідування у частині дій та застосування заходів, що обмежують права осіб. Ухвала слідчого судді як акт правозастосування відображає права і обов'язки суб'єктів, яких вона стосується, ї̈ постановлення впливає на відповідні процесуальні відносини. При цьому попередній судовий контроль забезпечує законність рішень та дій слідчого, дізнавача, прокурора, а не обмежує їх процесуальну самостійність не є втручанням в неї. 
Ключові слова: попередній судовий контроль, досудове розслідування, права і свободи особи, законність.

Актуальність теми. Попередній судовий контроль здійснює превентивний, попереджувальний, запобіжний вплив незацікавленого в результатах досудового розслідування, а отже, неупередженого уповноваженого спеціального суб'єкта - слідчого судді на процесуальні відносини, дії, рішення, пов'язані із можливим обмеженням прав осіб на досудовому розслідуванні. До них, насамперед, належать застосування заходів забезпечення кримінального провадження, проведення слідчих (розшукових) дій.

Аналіз останніх наукових публікацій. Наукові та практичні засади судового контролю на досудовому розслідуванні розглядали у своїх працях Ю.П. Аленін, О.В. Баулін, О.М. Бандурка, І.В. Гловюк, Ю.М. Грошевий, О.П. Кучинська, А.М. Ларін, Л.М. Лобойко, В.Т. Маляренко, М.А. Погорецький, B.О. Попелюшко, О.Ю. Татаров, В.М. Тертишник, А.Р. Туманянц, В.П. Шибіко, M.Є. Шумило, B.I. Фаринник, Л.Д. Удалова, О.Г. Яновська та інші науковці.

Метою статті $\epsilon$ визначення поняття, змісту, предмета, об'єкта, меж попереднього судового контролю на досудовому розслідувані.

Виклад основного матеріалу. Попередній судовий контроль - це діяльність слідчого судді, що полягає у наданні або відмові у наданні дозволу на застосування процесуальних заходів та здійснення процесуальних дій, які потребують такого дозволу відповідно до закону.

Як зазначено у Листі Вищого спеціалізованого суду України з розгляду цивільних і кримінальних справ № 223-559/0/4-13 від 5 квітня 2013 року «Про деякі питання здійснення слідчим суддею суду першої інстанції судового контролю за дотриманням прав, свобод та інтересів осіб під час застосування заходів забезпечення кримінального провадження», вирішуючи питання про застосування заходів забезпечення кримінального провадження, у кожному випадку розгляду відповідних клопотань слідчі судді зобов'язані:

- сумлінно і принципово здійснювати повноваження із судового контролю за дотриманням прав, свобод та інтересів осіб у кримінальному провадженні під час досудового розслідування, діяти у межах і відповідно до вимог закону;

- перевіряти наявність об'єктивної необхідності та виправданість такого втручання у права і свободи особи, з'ясовувати можливість досягнення мети, на яку посилається автор клопотання, без застосування цих заходів;

- зважати, що незалежно від визначеного процесуальним законом суб’єкта ініціювання застосування заходів забезпечення обов'язок довести наявність трьох необхідних складових для їх застосування (ч. 3 ст. 132 КПК) покладається на слідчого та/або прокурора;

- враховувати, що докази на підтвердження обставин, викладених у клопотанні про застосування заходів забезпечення, подаються особою, яка заявляє таке клопотання;

- пам'ятати, що суддя, який брав участь у кримінальному провадженні під час досудового розслідування, згідно з ч. 1 ст. 76 КПК не має права брати участь у цьому ж провадженні в суді як першої, так і апеляційної та 
касаційної інстанцій, а також при перегляді судових рішень Верховним Судом України або за нововиявленими обставинами [1].

Слід зважати, що лише з дозволу та на підставі ухвали слідчого судді проводяться процесуальні дії, під час яких має місце суттєве тимчасове обмеження прав та інтересів осіб. До переліку таких дій, крім негласних слідчих (розшукових), належать окремі слідчі (розшукові) дії, більшість заходів забезпечення кримінального провадження й інші процесуальні дії, а саме: привід (ч. 2 ст. 140 КПК); накладення грошового стягнення (ч. 2 ст. 144 КПК); тимчасове обмеження у користуванні спеціальним правом (ч. 2 ст. 148 КПК); відсторонення від посади (ч. 2 ст. 154 КПК); тимчасовий доступ до речей і документів (ч. 2 ст. 159 КПК); арешт майна (ч. 2 ст. 170 КПК); запобіжні заходи (ч. 4 ст. 176 КПК); знищення, передача для технологічної переробки або для реалізації речових доказів за відсутності згоди власника (ч. 6 ст. 100 КПК); обшук (ч. 2 ст. 234 КПК); огляд житла чи іншого володіння особи за відсутності добровільної згоди особи, яка ним володіє (ч. 2 ст. 237 КПК); слідчий експеримент, що проводиться в житлі чи іншому володінні особи, за відсутності добровільної згоди особи, яка ним володіє (ч. 5 ст. 240 КПК); примусове відібрання біологічних зразків для експертизи (ч. 3 ст. 245 КПК); примусове залучення особи для проведення медичної або психіатричної експертизи (ч. 3 ст. 242, ч. 2 ст. 509 КПК) тощо [2].

Отже, законодавець, визначаючи перелік дій і рішень, які підлягають попередньому судовому контролю тим самим визнає їх такими, що обмежують права і свободи учасників кримінального провадження, що узгоджується із загальною метою, призначенням контрольно-наглядової діяльності на досудовому розслідуванні та, відповідно, метою судового контролю зокрема. Тому слідчий суддя під час розгляду певного клопотання вирішує питання про доцільність обмеження прав і свобод, про ступінь їх обмеження і наявність підстав для обмежень.

Як зазначає К.В. Приходько, попереджувальний контроль має місце під час прийняття рішення слідчим суддею про проведення обшуку, обрання запобіжного заходу або застосування іншого заходу забезпечення кримінального провадження. Відповідно, предметом судового контролю у таких випадках не можуть виступати дії і рішення, які вже існують. На нашу думку, під час попереджувального контролю предметом має виступати саме рівень обмеження прав, свобод і інтересів осіб, що залучаються до кримінальної процесуальної діяльності.

Ця якісна характеристика, на нашу думку, є головним питанням і, відповідно, предметом судового контролю. Слід зазначити, що долучення до предмету судового контролю одних прав, свобод і інтересів осіб буде недостатньо. Є очевидним, що під час прийняття рішення про обмеження прав і свобод слідчий суддя вивчає, з одного боку, значимість розглядуваної дії для кримінального судочинства з огляду на його завдання, а з іншого боку досліджує необхідний рівень обмеження прав і свобод осіб, що залучені або можуть залучатися у майбутньому до провадження. Тому предметом судового контролю під час попереджувального його різновиду слід вважати рівень обмеження прав і свобод осіб, що залучаються до кримінальної процесуальної діяльності, що визначається можливістю реалізації завдань кримінального провадження [2]. 
О.В. Кондратьєв предметом попереднього судового контролю визначає дії і рішення, які: а) істотно обмежують конституційні права громадян; б) породжують наслідки, що виходять за рамки власне кримінально-процесуальних правовідносин; в) призводять до таких обмежень конституційних прав, що не можуть бути відновлені в результаті наступного судового контролю або судового розгляду [3, с. 40].

Відповідно ч. 1 ст. 132 КПК України, заходи забезпечення кримінального провадження застосовуються на підставі ухвали слідчого судді або суду, за винятком випадків, передбачених КПК України.

Заходи забезпечення кримінального провадження, а насамперед, запобіжні заходи завжди пов'язані із обмеженням прав осіб щодо яких вони застосовуються. Це твердження справедливе також і щодо проведення слідчих (розшукових) дій, негласних слідчих (розшукових) дій проведення яких потребує дозволу слідчого судді.

Як було зазначено, законодавець визначаючи перелік заходів забезпечення кримінального провадження та слідчих (розшукових) дій, негласних слідчих (розшукових) дій, які підлягають попередньому судовому контролю тим самим визнає, що саме ці дії і заходи пов'язані із обмеженням прав осіб, що потребує не тільки формального дозволу або заборони, а й дослідження підстав застосування згаданих дій і заходів неупередженим суб'єктом.

Таким чином, визначені дії і заходи, що потребують судового контролю становлять певну групу в основі формування якої - правообмежувальний характер таких дій і заходів, а обов'язковість судового контролю слугує юридичною гарантією дотримання законності, прав і свобод учасників провадження.

Обмеження прав і свобод повинно відповідати наступним вимогам: 1) правова визначеність щодо можливості обмеження, його ступеню та меж; 2) відповідність нормам міжнародного права і правовим позиціям ЄСПЛ; 3) незмінність сутнісного змісту права, яке обмежується і мінімальне втручання у його реалізацію для оптимального досягнення мети обмеження; 4) легітимна мета, суспільна необхідність її досягнення; 5) пропорційність; 6) постановлення вмотивованого судового рішення у порядку справедливої судової процедури.

Із урахуванням викладеного, можна зробити висновок, що попередній судовий контроль змістовно і функціонально спрямований на недопущення незаконного, надмірного, необгрунтованого обмеження прав, що означає його охоронне і превентивне призначення.

Крім запобігання порушенням і обмеженням, попередній судовий контроль також слугує юридичною гарантією недопустимості звуження прав і свобод осіб.

Системний аналіз норм КПК України, що стосуються попереднього судового контролю показав, що вони в цілому відповідають наступним вимогам: 1) є законодавчим оформленням (підтвердженням) можливості застосування заходів та здійснення дій, які обмежують (звужують) обсяг прав і свобод, тобто обмеження $\epsilon$ правомірним, порядок і випадки такого обмеження визначені в законі; 2) обмеження можуть бути застосовані щодо обсягу прав, а не їх сутності; 3) врахування актів міжнародного права, 
позицій ЄСПЛ (як у нормативному регулюванні, так і у правозастосуванні); 4) правові механізми орієнтовані на мінімальне втручання у реалізацію прав. Це, як убачається, узгоджується із визначеними умовами правомірного правообмеження.

Проте правозастосовна діяльність щодо реалізації попереднього судового контролю виявила низку проблем, які впливають на її якість та ефективність. До найбільш актуальних з них пропонуємо звернутись крізь призму змісту попереднього судового контролю.

Отже, зміст попереднього судового контролю становлять дії слідчого судді щодо з'ясування сукупності наступних обставин:

1) чи належить до повноважень слідчого судді розгляд клопотання (підсудність);

2) чи відповідає вимогам процесуальної форми клопотання, чи подане воно належним суб'єктом (крім слідчого (за погодженням з прокурором у визначених випадках), прокурора з клопотанням можуть звертатись інші суб'єкти: підозрюваний, його захисник, потерпілий, його представник (судовий виклик ст. 134 КПК України); сторони кримінального провадження (тимчасовий доступ до речей і документів ст. 160 КПК України); цивільний позивач (арешт майна ст. 171 КПК України).

3) чи передбачено КПК України можливість обмеження прав і свобод у зв’язку із здійсненням тієї або іншої процесуальної дії або заходу.

У якості прикладу звернемося до відомої практиці проблеми постановлення ухвали слідчим суддею, яка не передбачена КПК України, що також викликає складності щодо її оскарження.

У наступному рішенні ВРП розкрито її зміст та правову позицію ВС з цього питання.

Так, в ухвалі ВРП йдеться про те, що у скаргах Ругаль О.А. зазначає, що Кримінальний процесуальний кодекс України (далі - КПК України) не наділяє повноваженнями слідчого суддю на розгляд клопотань про призначення позапланової виїзної перевірки та не передбачає процедури розгляду такого виду клопотань, компетенцію слідчого судді щодо вирішення такого клопотання.

Скаржник вказує, що судді апеляційної інстанції зазначене не врахували, не врахували висновків, викладених у постановах Верховного Суду від 6 березня та 23 травня 2018 року у справі № 243/6674/17, посилаючись на те, що вони стосуються конкретних справ, інших обставин процесуальних норм права. Такі посилання $є$ необгрунтованими, оскільки у вказаних висновках надано правову оцінку законності саме ухвал слідчих суддів, що не передбачені кримінальним процесуальним законодавством. ...

Згідно із частиною другою статті 19 Конституції України органи державної влади та органи місцевого самоврядування, їх посадові особи зобов'язані діяти лише на підставі, в межах повноважень та у спосіб, що передбачені Конституцією та законами України.

Частиною першою ст. 1 КПКУкраїни визначено, що порядок кримінального провадження на території України визначається лише кримінальним процесуальним законодавством України.

Відповідно до частини першої ст. 9 КПК України під час кримінального провадження суд, слідчий суддя, прокурор, керівник органу досудо- 
вого розслідування, слідчий, інші службові особи органів державної влади зобов'язані неухильно додержуватися вимог Конституції України, цього Кодексу, міжнародних договорів, згода на обов'язковість яких надана Верховною Радою України, вимог інших актів законодавства.

Згідно зі статтею 21 КПК України кожному гарантується право на справедливий розгляд та вирішення справи в розумні строки незалежним і неупередженим судом, створеним на підставі закону. Кожен має право на участь у розгляді в суді будь-якої інстанції справи, що стосується його прав та обов’язків, у порядку, передбаченому цим Кодексом.

Відповідно до частини третьої ст. 26 КПК України слідчий суддя, суд у кримінальному провадженні вирішують лише ті питання, що винесені на їх розгляд сторонами та віднесені до їх повноважень цим Кодексом.

Згідно з пунктом 18 частини першої статті 3 КПК України слідчий суддя- суддя суду першої інстанції, до повноважень якого належить здійснення у порядку, передбаченому цим Кодексом, судового контролю за дотриманням прав, свобод та інтересів осіб у кримінальному провадженні». Таким чином, законодавець чітко визначив роль слідчого судді у системі кримінального судочинства: забезпечити, аби правоохоронні органи під час здійснення наданих їм повноважень не порушували права, свободи та інтереси особи.

КПК України не містить норм, що регламентують можливість та порядок звернення слідчого або прокурора із клопотанням про призначення позапланової виїзної документальної перевірки фінансово-господарської діяльності та розгляд слідчим суддею такого клопотання.

Вирішення слідчим суддею клопотань про надання дозволу на проведення позапланових перевірок у кримінальному провадженні не охоплюється його повноваженнями, визначеними КПК України, які мають реалізовуватися у передбачений процесуальним законом спосіб, адже не відносяться ні до заходів забезпечення кримінального провадження, ні до слідчих дій, ні до негласних слідчих дій. Це суперечить самій суті судового контролю над діями і рішеннями державних органів з метою захисту прав, свобод та інтересів осіб. Це також суперечить завданню суду як інституції в демократичному суспільстві.

Також з ухвали Верховного Суду від 6 березня 2018 року у справі № 243/6674/17-к, якою кримінальне провадження за касаційною скаргою представника товариства з обмеженою відповідальністю «Науково-виробниче об'єднання «Синтоп» на ухвалу апеляційного суду Донецької області від 30 серпня 2017 р. про відмову у відкритті апеляційного провадження (за апеляційною скаргою на ухвалу слідчого судді про надання дозволу на проведення комплексної позапланової перевірки) передано на розгляд Великої Палати Верховного Суду, вбачається, що під час дослідження поширеності практики надання слідчими суддями дозволів на призначення позапланових перевірок Верховний Суд виявив суперечність судової практики із цих питань. При цьому Верховний Суд встановив, що слідчий суддя, надавши слідчому дозвіл на проведення перевірки, вийшов за межі своїх повноважень і прийняв рішення, не передбачене кримінальним процесуальним законодавством. 
Постановою Великої Палати Верховного Суду від 23 травня 2018 р. у цій справі ухвалу апеляційного суду Донецької області від 30 серпня 2017 р. скасовано та призначено новий розгляд у суді апеляційної інстанції.

Зазначені факти, а також ненаведення мотивів прийняття судового рішення суддею Новозаводського районного суду м. Чернігова Деркачом О.Г. можуть свідчити про порушення права на справедливий судовий розгляд безстороннім судом та вчинення вказаним суддею дисциплінарних проступків, передбачених підпунктами «а», «б» пункту 1 частини першої статті 106 Закону України «Про судоустрій і статус суддів» у редакції, чинній на час постановлення ухвали, відповідно до яких суддю може бути притягнуто до дисциплінарної відповідальності в порядку дисциплінарного провадження з підстав умисного або внаслідок недбалості істотного порушення норм процесуального права під час здійснення правосуддя, що унеможливило учасниками судового процесу реалізацію наданих їм процесуальних прав та виконання процесуальних обов'язків, та не зазначення в судовому рішенні мотивів прийняття або відхилення аргументів сторін щодо суті спору [4]. Отже, у подібних випадках результатом судового контролю мав би бути висновок про відсутність у КПК України положень, які передбачають можливість ініціювання позапланових ревізій і перевірок слідчим, прокурором, а отже і неможливість постановлення суддею рішення про дозвіл або відмову у дозволі на їх проведення. Відповідно до ч. 3 ст.26 КПК України слідчий суддя, суд у кримінальному провадженні вирішують лише ті питання, що винесені на їх розгляд сторонами та віднесені до їх повноважень цим Кодексом, а тому слідчий суддя повинен мати повноваження для ухвалення певного рішення, у КПК України має бути визначено процедуру і умови його прийняття.

4) які саме обмеження є правомірними для певної дії або заходу.

5) чи є обмеження, про яке йдеться у клопотанні пропорційним (необхідним і не надмірним) у відповідній ситуації і щодо певної особи.

6) чи вирішить застосування обмеження певне завдання досудового розслідування (збирання доказів, запобігання ризикам, визначеним у ст. 177 КПК України та ін.).

Таким чином, попередній судовий контроль включає перевірку слідчим суддею дотримання формальних вимог та оцінку доказів у частині вимог, визначених КПК України до змісту клопотання про проведення процесуальної дії або заходу, що у кожному випадку передбачають обгрунтування та підтвердження доказами такої необхідності.

Вимога щодо обгрунтування необхідності проведення процесуальних дій і заходів та підтвердження доказами існування певних обставин означає, що об'єктивно можуть існувати сумніви у їх законності, необхідності та доцільності як щодо виконання завдань кримінального провадження, так і щодо певної особи, а отже існує потреба у здійсненні судового контролю.

При цьому різні вимоги до змісту клопотань про проведення процесуальних дій і заходів визначають специфіку, зміст та межі попереднього судового контролю.

Так, наприклад, розглядаючи клопотання про застосування запобіжного заходу (ст. 193 КПК України), слідчий суддя керується завданнями 
кримінального провадження, загальними засадами кримінального провадження у відповідній частині, загальними правилами застосування заходів забезпечення кримінального провадження, загальними правилами застосування запобіжних заходів, а також нормами, які визначають порядок його діяльності для конкретного запобіжного заходу.

Слідчий суддя оцінює достатність даних, якими уповноважений суб'єкт обгрунтовує законність і необхідність застосування саме обраного запобіжного заходу та обгрунтованість підозри.

Як було зазначено, особливістю попереднього судового контролю $є$ те, що він здійснюється щодо можливості виконання рішень і дій уповноважених суб'єктів, які ними ініційовані, але не реалізовані із одночасною оцінкою фактичних даних, якими обгрунтовано відповідне клопотання про їх необхідність. Обгрунтування може містити як посилання на об'єктивно існуючі обставини, так і їх прогнозування (наприклад, ризики, визначені ст. 177 КПК України).

Наведене дає підстави для визначення об'єкта, предмета, меж попереднього судового контролю.

Об’єктом попереднього судового контролю є кримінальні процесуальні відносини, пов'язані із застосуванням заходів забезпечення кримінального провадження, проведення процесуальних дій, що потребують дозволу слідчого судді.

Предмет попереднього судового контролю ми розглядаємо крізь призму його однаково важливих складових, а саме формальної - ініційоване та обгрунтоване уповноваженим суб'єктом звернення до слідчого судді, що відповідає вимогам процесуальної форми щодо можливості здійснення дій та заходів, які потребують постановлення ухвали слідчого судді; змістовної - сукупність даних, обставин, умов, з урахуванням яких слідчий суддя постановляє рішення про дозвіл або відмову у дозволі для проведення певних процесуальних дій та заходів.

Межі попереднього судового контролю визначаються:1) стадією досудового розслідування; 2) предметом контролю; 3) обсягом дослідження обставин на які посилається уповноважений суб'єкт для обгрунтування необхідності здійснення ініційованих дій і заходів; 4) процесуальним порядком дій слідчого судді.

Тут потрібно звернутись до іще однієї відомої проблеми щодо меж дослідження фактичних даних слідчим суддею, а, насамперед, одного з найбільш складних та спірних питань у доктрині і правозастосуванні - стандарту доказування «обгрунтована підозра».

Тлумачення нормативної вимоги обгрунтованості підозри виявило низку суперечностей, які складно вирішити. 3 одного боку, слідчий суддя не вирішує питання про винуватість особи під час здійснення судового контролю, а з іншого, він зобов'язаний прийняти рішення на основі дослідження відповідних доказів, інакше його роль зведеться тільки до перевірки дотримання формальних вимог до клопотання, що, очевидно, не відповідає меті судового контролю.

ЄСПЛ у низці рішень сформулював правову позицію, яка використовується у правозастосуванні і $є$ визнаним правовим стандартом (стандартом доказування), вона полягає у тому, що підозра має грунтуватись на розумних 
підставах, за наявності фактів і обставин, які можуть переконати об'єктивного спостерігача у тому, що підозрюваний міг вчинити кримінальне правопорушення (злочин). Законність арешту або затримання не означає достатності доказів для обвинувачення, факти, якими обгрунтовано підозру не обов'язково повинні відповідати такому ступеню переконливості як ті, що необхідні для пред’явлення обвинувачення («Фокс, Кемпбелл і Хартлі проти Сполученого Королівства», «Мюррей проти Сполученого Королівства», «Нечипорук і Йонкало проти України», «Влох проти Польщі» та ін.).

Наприклад, в ухвалі Київського апеляційного суду зазначено, що розглядаючи клопотання про застосування запобіжного заходу у вигляді тримання під вартою для прийняття законного і обгрунтованого рішення, суд, відповідно національного та міжнародного законодавства повинен врахувати тяжкість кримінального правопорушення, у вчиненні якого підозрюється особа та особисті обставини життя особи, які можуть свідчити на користь збільшення (зменшення) ризику переховування від правосуддя чи інших способів неналежної процесуальної поведінки.

Згідно положень ч.1 ст.183 КПК України тримання під вартою є винятковим запобіжним заходом, який застосовується виключно у разі, якщо прокурор доведе, що жоден із більш м'яких запобіжних заходів не зможе запобігти ризикам, передбаченим ст. 177 цього Кодексу, крім випадків, передбачених частиною п'ятою ст. 176 цього Кодексу.

Під час розгляду зазначеного клопотання слідчий суддя правильно встановив, що наведені у ньому дані, виклад яких зроблено з посиланням на матеріали кримінального провадження, свідчать про наявність обгрунтованої підозри у вчиненні ОСОБА_1 інкримінованого йому кримінального правопорушення, передбаченого ч. 3 ст. 289 КК України.

Як вбачається з ухвали слідчого судді, журналу судового засідання та технічного запису, на основі наданих слідчим матеріалів в додатках до клопотання, які його обгрунтовують, слідчий суддя встановив, що зазначені у клопотанні обставини підозри мають місце і підтверджуються на цьому етапі розслідування достатньою сукупністю даних, детальний перелік яких міститься в клопотанні слідчого, а документи, які містять такі дані, надані до суду разом з клопотанням.

Враховуючи, що слідчий суддя на цьому етапі провадження не вправі вирішувати ті питання, які повинен вирішувати суд під час розгляду кримінального провадження по суті, зокрема, не вправі оцінювати докази з точки зору їх достатності і допустимості для визнання особи винною чи невинною у вчиненні злочину, а лише зобов'язаний на підставі розумної оцінки сукупності отриманих доказів визначити, що причетність особи до вчинення кримінального правопорушення $\epsilon$ вірогідною та достатньою для застосування щодо неї обмежувального заходу, то з огляду на наявні в матеріалах провадження дані у слідчого судді були всі підстави для висновку про наявність обгрунтованої підозри у вчиненні ОСОБА_1 кримінального правопорушення, передбаченого ч.3 ст. 289 КК України.

Більш того, якщо виходити з поняття «обгрунтована підозра», приведеного в п. 175 рішення Європейського суду з прав людини від 21.04.2011 p. у справі «Нечипорук і Йонкало проти України», то обгрунтована підозра означає, що існують факти і інформація, які можуть переконати об'єктивного 
спостерігача, що особа, про яку йдеться, могла вчинити правопорушення. Вимога розумної підозри передбачає наявність доказів, які об'єктивно зв'язують підозрюваного з певним злочином і вони не повинні бути достатніми, щоб забезпечити засудження, але мають бути достатніми, щоб виправдати подальше розслідування або висунення звинувачення (рішення у справі «Мюррей проти Об'єднаного Королівства» від 28.10.1994 р., «Фокс, Кемпбелл і Гартлі проти Сполученого Королівства» від 30.08.1990р.).

Фактів і інформації, які переконливо свідчать про причетність ОСОБА_1 до вчинення вищевказаного кримінального правопорушення в клопотанні слідчого та доданих до нього матеріалах міститься достатньо для висновку про обгрунтованість повідомленої йому підозри [5].

Потрібно погодитись, із позицією, відповідно до якої попередній судовий контроль не вирішує питання про винуватість, передбачає дослідження обгрунтованості підозри, а не обвинувачення.

У разі, коли цей запобіжний захід обирається щодо обвинуваченого, тобто особи, щодо якої $є$ достатні підстави для обвинувачення у вчиненні злочину, суд не вправі вимагати від слідчих органів надання сукупності доказів винуватості особи і здійснювати їх перевірку і оцінку. Останнє є завданням більш пізніх етапів кримінального судочинства. В умовах діючої моделі досудового розслідування інше означало б порушення дискреційної самостійності сторони обвинувачення в питаннях пред'явлення і підтримання кримінального позову і очевидне вирішення судом питання про винуватість особи в рамках процедури, що має зовсім інші задачі. Обвинувачення як таке і докази винуватості особи у вчиненні злочину є предметом вирішення справи по суті, а не розгляду клопотання про взяття під варту [6, с. 59].

Висновок. Отже, попередній судовий контроль являє сукупність пов'язаних дій щодо перевірки законності рішень і дій органу досудового розслідування (відповідність дій і рішень вимогам законодавства, що регулює діяльність органу досудового розслідування та у межах визначених повноважень), обгрунтованості таких дій і рішень, а також підтвердження або спростування юридичного значення дій і рішень уповноважених органів, що у комплексі забезпечує, крім законності, стабільність, передбачуваність досудового розслідування у частині дій та застосування заходів, що обмежують права осіб. Ухвала слідчого судді як акт правозастосування відображає права і обов'язки суб’єктів, яких вона стосується, її постановлення впливає на відповідні процесуальні відносини. При цьому попередній судовий контроль забезпечує законність рішень та дій слідчого, дізнавача, прокурора, а не обмежує їх процесуальну самостійність не є втручанням в неї.

\section{СПИСОК ВИКОРИСТАНИХ ДЖЕРЕЛ}

1. Про деякі питання здійснення слідчим суддею суду першої інстанції судового контролю за дотриманням прав, свобод та інтересів осіб під час застосування заходів забезпечення кримінального провадження: Лист Вищого спеціалізованого суду України з розгляду цивільних і кримінальних справ від 5 квіт. 2013 р. № 223-559/0/4-13. URL: https://zakon.rada.gov.ua/ laws/show/v0558740-13\#Text

2. Приходько К. В. Предмет і мета судового контролю на стадії досудового розслідування. Правничий часопис Донецького університету. 2013. № 2. С. 199-207. 
3. Кондратьєв О. В. Організаційно-правові проблеми судового контролю: дис. ... канд. юрид. наук : 12.00.10. Харків. 2005. 191 с.

4.Ухвала Вищої ради правосуддя від 11 жовт. 2019 року № 2668/1дп/1519. URL: hcj.gov.ua.

5. Ухвала Київського апеляційного суду від 25 серп. 2020 р. № 757/31220/20-к. URL: http://reyestr.court.gov.ua/Review/91260743

6. Судебное санкционирование как форма реализации правосудия в уголовном судопроизводстве России: монография / Э.А. Адильшаев, И.В. Жеребятьев, А.А. Шамардин. ООО ИПК «Университет». 2013. 277 с.

\section{Mirkovets}

\section{PRELIMINARY JUDICIAL CONTROL AS A GUARANTEE LEGALITIES OF PRE-TRIAL INVESTIGATION AND MEANS OF ENSURING THE RIGHTS OF PERSONS}

The relevance of the article is that the preliminary judicial control has a preventive, precautionary, preventive effect of disinterested in the results of the pre-trial investigation, and therefore impartial authorized special entity investigating judge on procedural relations, actions, decisions related to possible restriction of rights persons on pre-trial investigation. These, first of all, include the application of measures to ensure criminal proceedings, conducting investigative (search) actions. The decision of the investigating judge on requests for permission to conduct unscheduled inspections in criminal proceedings is not covered by his powers defined by the CPC of Ukraine, which must be implemented in the manner prescribed by procedural law, because they do not apply to criminal proceedings, investigative actions or covert investigative actions. This contradicts the very essence of judicial control over the actions and decisions of state bodies in order to protect the rights, freedoms and interests of individuals. It also runs counter to the task of the court as an institution in a democratic society. It was found that the decision of the Kyiv Court of Appeal states that when considering a request for the application of a measure of restraint in the form of detention to make a lawful and reasonable decision, the court, in accordance with national and international law personal circumstances of a person's life that may indicate an increase (decrease) in the risk of absconding from justice or other means of misconduct. It is concluded that the preliminary judicial control is a set of related actions to verify the legality of decisions and actions of the pre-trial investigation body (compliance of actions and decisions with the legislation governing the pre-trial investigation body and within certain powers), the validity of such actions and decisions, and also confirmation or refutation of the legal significance of actions and decisions of authorized bodies, which in the complex provides, in addition to legality, stability, predictability of pre-trial investigation in terms of actions and application of measures restricting the rights of persons. The decision of the investigating judge as an act of law enforcement reflects the rights and obligations of the subjects to whom it applies, its decision affects the relevant procedural relations. At the same time, preliminary judicial control ensures the legality of decisions and actions of the investigator, coroner, prosecutor, and does not limit their procedural independence is not an interference in it.

Keywords: preliminary judicial control, pre-trial investigation, rights and freedoms of a person, legality. 